\title{
WHO and the epidemic of cesarians
}

It is the role of the journal to announce national or international documents on scientific and political interests and innovation on maternal and child health problems, the Brazilian Journal of Mother and Child Health publishes this issue as an Editorial, on the new position from the World Health Organization ${ }^{1}$ (WHO) about the abuse of current cesareans interventions. The document is timely and relevant for Brazil, which rises along with Nicaragua, the statistics on the highest rates of cesarean sections in the world scale.

In the last century and, above all from the 1950's, health in the world has gone through radical changes, considering rapid changes in fertility, morbidity and mortality patterns. This process known as "epidemiological transition", with its own evolution for each disease, in addition to the most complex events of generic characteristics that define the process of transition, have as a common denominator of polarizing the passage on infections/nutritional deficiencies for a new epidemiological model dominated by non-transmittable chronic diseases (NTCD) which currently brings together around $70 \%$ of death causes in the world, $268 \%$ only in Brazil. 3

In this context of great and rapid changes, which makes the problem of cesareans as epidemic, is the fact that a health intervention for starters should have been designed and applied as an instrument of protection, pursuing and even fulfilling this important role, has joined in the risk factor category, characterizes as an iatrogenic epidemic. In fact, adverse effects on health interventions, whether it is at diagnostic procedure levels, under therapeutic medications or surgical conducts or even in the establishment inside and outside of the health area, representing a social iatrogenesis, establishes in fact, a new context in each level on health/disease problems and practically in all the countries, whether it is rich or poor. And in this perspective and its multiple positive and negative consequences that projects the new document from the World Health Organization, released in the month of February and formally forwarded to all the governments in the world. 4

In the temporal and geographical configuration of the problem, the WHO says that the index of deliveries performed by cesarean section was $6 \%$, in 1980 , tripling to $18.6 \%$ in 2016 , which is referred as the base year for the most recent analysis on international statistics on the mentioned theme. In Europe, the index increased 20 years ago from $15 \%$ to $25 \%$, in other words, a quarter of all children were born alive. Currently, in the United States about $33 \%$ of childbirths turn to the use of surgeries. Therefore, it is an exception which, unfortunately, is now assuming the indication of a general rule.

It is pertinent to emphasize that, in formal terms Brazil has an interesting history in relation to pursue a universal consensus on the interventions for cesarean section standardization. Just as a reminder, it was in Fortaleza city in Ceará State that performed along with the sponsorship of WHO on the first international document on recommended practices of childbirth hospital care, establishing as a guideline rate of $12 \%$ to $15 \%$ of cesarean sections. The validation document was fundamental then on the data from a few countries with advanced socioeconomic development level. However, until today it is a question of public and more referred technical consense than as a normative principle of policies, programs and professionals conducts on the cesarean sections resource. 5,6

Until now, adopting new concepts, perspectives and recommendations based on hundreds of assessments, covering most of the countries, the WHO after what could be called a "Consenso de Fortaleza" (Consensus in Fortaleza), publishes a new document position on the issue of cesarean interventions, which are becoming one of the most epidemics in the modern world. The new instructions are based on 56 observations or recommendations with principles and rules of conduct to be consulted within the challenge to redeem natural childbirth. 
It is very timely and relevant to consider this case in Brazil, which is already in the same level along with Nicaragua of $56 \%$ of cesarean sections, with the largest worldwide prevalence configuring as a promising contrary movement in the same way that has already occurred in relation to the national and global problem of early weaning. This mobilization may very well be represented by the initiative of "doulas", that already exist in many countries, as volunteers or professionals who are willing to help mothers, families and health professionals (obstetricians, especially) in the critical period since the entry of the parturients in the maternities until the childbirth outcomes. Partially, in the updated version, the ancient customs in history of the normal childbirth, which this may represent a decisive role in the reversal epidemic trend on cesarean sections in Brazil and in the world. To the extent that the participation of "doulas" is still restricted to private health services, this exists in almost all the States in Brazil, its reappearance as a recycled tradition represents a potential prospect for its extension to the public services of obstetrics, becoming a fully viable strategy as volunteer work or as a professional task. ${ }^{7}$ Thus, an updated reconstitution of a tradition that nowadays is part of the oldest memories in childbirth that can be revived with its own logic, the normative conducts in the obstetric services.

\section{References}

1. WHO (World Health Organization). WHO Statement on Caesarean Section Rates.Geneva; 2015(WHO/RHR/15.02)

2. WHO (World Health Organization). Global status report on noncommunicable diseases 2014. Geneva; 2014.298 p. [acesso em 12 mar 2017]. Disponível em: http://www.who.int/nmh/publications/ncd status report 2014/en/

3. Carvalho SPS, Cesse EDP, Lira PIC, Rissin A., Cruz RSBLC, Batista Filho M. Doenças crônicas não transmissíveis e fatores associados em adultos numa área urbana de pobreza do Nordeste Brasileiro. Ciênc Saúde Coletiva. (2018/Fev). [Citado em 09/03/2018]. Disponível em: http://www.cienciaesaudecoletiva.com.br/artigos/doencas-cronicas-nao-transmissiveis-e-fatores-ass o c i a d o s - e m-a d u l to s - n u m a - a r e a - u r b a n a - d e - pobreza-do-norde stebrasileiro/16587? id=16587\&id=16587\&id=16587\&id=16587\&id=16587\&id=16587

4. WHO (World Health Organization). WHO recommendations: intrapartum care for a positive childbirth experience. Geneva; 2018. Licence: CC BY-NC-SA 3.0 IGO. Cataloguing-in-Publication (CIP) data. CIP data are available at http://apps.who.in

5. Betran AP, Torloni MR, Zhang J, Ye J, Mikolajczyk R, Deneux-Tharaux C, Oladapo OT, Souza JP, Tunçalp Ö, Vogel JP, Gülmezoglu AM. What is the optimal rate of caesarean section at population level? A systematic review of ecologic studies. Reprod Health. 2015; 12 (1): 57.

6. Vogel JP, Betrán AP, Vindevoghel N, Souza JP, Torloni MR, Zhang J, Tunçalp Ö, Mori R, Morisaki N, Ortiz-Panozo E, Hernandez B, Pérez-Cuevas R, Qureshi Z, Gülmezoglu AM, Temmerman M, WHO Multi-Country Survey on Maternal and Newborn Health Research Network. On behalf of the WHO Multi-Country Survey on Maternal and Newborn Health Research Network. Use of the Robson classification to assess caesarean section trends in 21 countries: a secondary analysis of two WHO multicountry surveys. Lancet Global Health. 2015; 3 (5): e260-70.

7. Silva RM, Barros NF, Jorge HMF, Melo LPT, Ferreira Junior AR. Evidências qualitativas sobre o acompanhamento por doulas no trabalho de parto e no parto. Ciênc Saúde Coletiva. 2012; 17 (10): 2783-94.

\section{Malaquias Batista Filho 1}

Anete Rissin 2

1,2 Instituto de Medicina Integral Prof. Fernando Figueira. Recife, PE, Brazil. 